Vol 11, Issue 11, 2018

\title{
INVESTIGATION ON IN VIVO ANALGESIC ACTIVITY OF METHANOL EXTRACT OF MARINE BROWN ALGA SPATOGLOSSUM ASPERUM J. AGARTH
}

\author{
PANDITHURAI $\mathbf{M}^{1}$, MURUGESAN S ${ }^{1}$, SIVAMURUGAN V ${ }^{2 *}$ \\ ${ }^{1}$ Department of Botany, Division of Algal Biotechnology and Bionano Technology, Pachaiyappa's College, Chennai, Tamil Nadu, \\ India. ${ }^{2}$ Department of Chemistry, Pachaiyappa's College, Chennai, Tamil Nadu, India. Email: sivaatnus@gmail.com
}

Received: 06 June 2018, Revised and Accepted: 16 July 2018

\section{ABSTRACT}

Objective: In the present study, evaluation of the methanol extract of Spatoglossum asperum, brown marine algae on the analgesic activity using animal model was focussed.

Methods: Acetic acid-induced writhing test on Wistar albino rats at a dosage of $10 \mathrm{mg} / \mathrm{kg}$ body weight of algal extract have been carried out. It showed significant analgesic activity by reducing the number of acetic acid-induced writhing.

Results: The animals at a dosage of $10 \mathrm{mg} / \mathrm{kg}$ body weight exhibited, $70.52 \%$ of the animals were protected using $S$. asperum extract, on the other hand, the standard, diclofenac protected $84.21 \%$ of the animals. The results are statistically significant at p<0.001, and the investigation revealed dose-dependent significant activity in comparison with standard and control.

Conclusion: Hence, it can be concluded that the methanol extracts of the brown alga S. asperum have potent analgesic activity at moderate doses.

Keywords: Acetic acid writhing, Analgesic, Methanol extract, Spatoglossum asperum.

(C) 2018 The Authors. Published by Innovare Academic Sciences Pvt Ltd. This is an open access article under the CC BY license (http://creativecommons. org/licenses/by/4. 0/) DOI: http://dx.doi.org/10.26949/ajpcr.2018.v11i11.27760

\section{INTRODUCTION}

An analgesic or painkiller is any member of the group of drugs used to achieve (analgesia) relief from pain [1]. For neuropathic pain, traditional analgesics are less effective, and the drugs based on tricyclic antidepressants and anticonvulsants could be often showed benefit as analgesics [2]. Analgesia is associated with several pathological conditions.

The drug with lesser side effects would be a viable option when selecting a drug for the treatment of any ailments. Several ongoing studies around the globe have been involved to identify the healing agents based on natural sources. Consequently, there are many natural products that exhibit analgesic properties with relatively low incidences of side effects have been reported $[3,4]$. An increasing number of studies on the drugs of marine origin are demonstrating that many compounds produced by marine life have useful pharmacological activities. Among these organisms, the macroalgae are considered to be a rich source of bioactive substances suitable for therapeutic medical applications in analgesics [5-9].

Among the algae, brown algae are one of the most interesting phyla with respect to pharmacologically active compounds, were investigated widely in the past decade [10]. Nevertheless, there are many natural products that exhibit anti-inflammatory and analgesic properties and have relatively low incidences of side effects. An increasing number of studies on marine flora and fauna are demonstrating that many compounds produced by marine life have useful pharmacological activities. Among these organisms, the macroalgae are considered to be a rich source of bioactive substances suitable for therapeutic medical applications including use as an antiprotozoal [8], antibacterial [11-16], antifungal [17-22], antiviral [23], antioxidant [24-26], antidiabetic [27-29], antiinflammatory [23], and analgesics $[5,7,9]$.

\section{METHODS}

Sample collection and preparation

The samples of experimental marine brown alga, Spatoglossum asperum was collected from the Mandapam coast (Lat. $09^{\circ} 17.417^{\prime} \mathrm{N}$;
Long. $079^{\circ} 08.558^{\prime} \mathrm{E}$ ) of the Gulf of Mannar. The alga was authenticated by the monograph of Phaeophyceae [30]. Then, the alga was washed thoroughly with sterilized seawater to remove extraneous materials. The sample was shade dried to constant weight obtained and ground. The powdered samples were stored in an airtight container for future use.

Preparation of algal extracts

About $50 \mathrm{~g}$ of dried seaweed powder was soaked in the methanol solvent $(1: 3 \mathrm{w} / \mathrm{v})$ and kept in a hot air oven overnight at $323 \mathrm{~K}$, and the extracts were collected and concentrated. The extract was then filtered through a Buchner funnel with Whatman No.1 filter paper. The filtrate was evaporated to dryness under pressure using a rotary vacuum evaporator at $323 \mathrm{~K}$, and the crude extracts were weighed. The yield of the powdered extract obtained was $5 \mathrm{~g}$ (yield: 10\%) in methanol solvent. These crude extracts were then tested for their analgesic activity.

\section{Selection of animals}

Wistar albino rats, weighing 180-220 g of their body weight were selected for writhing analgesic method by Eddy's hot plate method and carrageenan-induced rat paw edema antiinflammatory effects. They were housed in polypropylene cages and maintained in standard laboratory conditions.

\section{Acetic acid induced writhing test}

The methods of Koster et al. (1959); Williamson et al. (1996) and García et al. (2004) were used [31-33]. Mice were used in three animals per group per dose of methanolic extract of $S$. asperum. The animals were kept individually in transparent perspex cages $(25 \mathrm{~cm} \times 15$ $\times 15 \mathrm{~cm}$ ) for $30 \mathrm{~min}$ to acclimatize to their new environment before the commencement of the experiment. Control mice were pre-treated with normal saline in a volume of $1 \mathrm{~mL} / 100 \mathrm{~g}$ of body weight, and after 15 min each mouse was injected with $0.2 \mathrm{~mL}$ of $3 \%$ acetic acid. $5 \mathrm{~min}$ after the administration of acetic acid, the writhes were counted for 20 min. Other groups of animals were pre-treated with algal extract, 
Table 1: Analgesic activities of methanolic extract of $S$, asperum on acetic acid-induced writhing reflux in rats

\begin{tabular}{|c|c|c|c|}
\hline Groups & Dose (mg/kg) & $\begin{array}{l}\text { No. of } \\
\text { writhing }\end{array}$ & $\begin{array}{l}\% \text { reduction in } \\
\text { reaction time }\end{array}$ \\
\hline Normal control (Group I) & Inject $1 \% \mathrm{v} / \mathrm{v}$ acetic acid $1 \mathrm{~mL} / 100 \mathrm{~g}$ of body weight & $38.0 \pm 3.5$ & - \\
\hline Positive control diclofenac sodium (Group II) & 10 mg/kg/body weight I. P. diclofenac sodium & $6.0 \pm 0.8$ & $84.21 \%{ }^{* *}$ \\
\hline $\begin{array}{l}\text { Treatment control (methanolic extract of } \\
\text { S. asperum (Group III) }\end{array}$ & $10 \mathrm{mg} / \mathrm{kg} /$ body weight administered through orally & $11.2 \pm 2.0$ & $70.52 \% * *$ \\
\hline
\end{tabular}

Values are expressed as mean \pm standard error of the mean. Values were found out by using one-way ANOVA followed by Newman's cause multiple range tests. **Values

were considered significant at $\mathrm{P}<0.001$. S. asperum: Spatoglossum asperum

15 min before injecting them intraperitoneally with $0.2 \mathrm{~mL}$ of $3 \%$ acetic acid. All experiments were performed between 08:00 and 16:00 $\mathrm{h}$ in a quiet laboratory with an ambient temperature of $298 \pm 2 \mathrm{~K}$. The ability of the algal extract was significantly reduced the number of acetic acid-induced writhes was taken as an analgesic activity. Animal experiments were performed in accordance with the CPCSEA norms and are approved by the Institute of Animal Ethical Committee (IAEC) No: IAEC/KMCP/153/FT/9599/2013-2014.

\section{Statistical analysis}

All animal experiments were performed with at least 7 mice per group, and the highest and lowest values were discarded. Data are presented as means \pm standard error. The significance of the results was calculated using one-way ANOVA using SPSS 17.0, and the differences were deemed statistically significant at $\mathrm{p}<0.01$

\section{RESULTS}

The methanol extract of $S$. asperum (10 mg/kg body weight) showed significant analgesic activity by reducing the number of acetic acidinduced writhes (Table 1 ). The analgesic activity of $S$. asperum at a dose of $10 \mathrm{mg} / \mathrm{kg}$ body weight on acetic acid-induced writhing reflex could be clearly observed and nearly, $70.52 \%$ of the animals were protected as against $S$. asperum, whereas $84.21 \%$ by diclofenac $(10 \mathrm{mg} / \mathrm{kg}$ body weight), a standard peripherally acting analgesic drug. The observed results are statistically significant at $p<0.001$. Many studies have found interesting biological activities in polar fractions from marine algae [34], and similar results were also obtained in our study.

The results of the present study showed a presence of triterpenes and steroids. Some of these compounds such as phenols, terpenes, polysaccharides, and steroids have been reported to possess antiedematous effects [23,35-41]. In agreement with these reports, it is possible that such compounds are present in the methanol extract of $S$. asperum and are able to inhibit the synthesis, release of inflammatory mediators involved in inflammation.

\section{DISCUSSION}

The present study demonstrated that the extracts, as well as structurally diverse compounds obtained from marine brown and green seaweeds, have been shown to inhibit inflammation [42]. The compounds in the seaweed extracts may play as competitive inhibitors of cyclooxygenase or lipoxygenase in an inflammation reaction, resulting in decreased production of prostaglandins and leukotrienes $[43,44]$.

The analgesic test used in the present study was chosen to test the different nociceptors stimuli, namely cutaneous thermic and chemical visceral stimuli [45]. In acetic acid-induced abdominal writhing causes analgesia by liberating endogenous substances and many others excite pain to the never-ending. Based on the percentage inhibition on the number of writhes obtained with different doses of methanol extract of $S$. asperum, it was found that the intensity of the analgesic effect was similar to that of the diclofenac. Diclofenac and related drugs can inhibit cyclooxygenase in peripheral tissues, thus interfering with mechanical transduction in primary afferent nociceptors. The ostagladina amplify the pain mechanism and enhance vascular permeability while the leukotrienes contract smooth muscle of blood vessels. Prostaglandins also enhance the vascular permeability and mediate pro-inflammatory and allergic responses $[46,47]$. The results of the present study showed that all the doses of the methanol extract of $S$. asperum produce a significant analgesic effect which may be due to the release of endogenous substances that stimulate pain in nerve endings similar to diclofenac. The methanol extract of $S$. asperum antagonized the pain produced by the acetic acid analgesic test method; it is possible that the seaweed produces its analgesic activity both peripherally and centrally.

The treatment of animals with the methanol extracts of $S$. asperum has shown significant inhibition of the writhing induced by $1.0 \%$ acetic acid solution. The maximum reduction in the number of writhing was $70.52 \%$, although the dose required to be higher than the acetic acid dose required for a similar effect. Nevertheless, all doses given were found to be more potent. The doses of positive control showed the percentage of reductions in the number of writhing of $84.21 \%$. The search for new metabolites from marine organisms has resulted in the isolation of some compounds such as terpenes, peptides, and sulfated carbohydrates that exhibit analgesic effects $[7,48,49]$. The analgesic activity observed may be associated with the presence of such compounds and other secondary metabolites in the methanolic extract of $S$. asperum, which are able to inhibit the release of endogenous mediators in response to acetic acid.

In the present investigation, confirmed that the methanolic extract of $S$. asperum has potent anti-inflammatory activity at moderate doses. This result suggests that the constituents in the algal extract could inhibit chemical mediators responsible for inflammation and that the inhibitory role in the migration of leukocytes to the site of inflammation is a strong indication in this study. This could, therefore, support the anti-inflammatory property of the $S$. asperum. Therefore, the results possess significant analgesic activity as compared to the control group in the pain model in vivo, with no serious toxic effect at moderate doses. The present findings reinforce the claims of the health-care industry and indigenous medicine that $S$. asperum can be used as a remedy for inflammation-related symptoms. Further, chemical analysis of the methanolic extract of $S$. asperum is necessary to isolate and identify the bioactive compounds that may have potential applications in therapeutic fields as analgesics. It is also understood that the rich diversity of marine biota with its unique physiological adaptations to the harsh marine environment provides a fruitful source for the discovery of life-saving drugs.

\section{CONCLUSION}

The marine brown alga $S$. asperum antagonized the pain produced by acetic acid writhing test methods; it is possible that the seaweed produces its analgesic activity both peripherally and centrally. The present study confirmed that the methanol extracts of the brown alga S. asperum have potent analgesic activity at moderate doses. This result also suggests that the constituents in this extract could inhibit chemical mediators responsible for analgesic activity is a strong indication in this study.

\section{AUTHORS' CONTRIBUTIONS}

All authors have contributed in the completion of this research work. 


\section{CONFLICTS OF INTEREST}

Authors have none to declare.

\section{REFERENCES}

1. Harper D. Online Etymology Dictionary: Analgesia. 2001, Available from: https://www.etymonline.com/word/analgesia. [Last accessed on 2012 Dec 03].

2. Dworkin RH, Corbin AE, Young JP. Pregabalin for the treatment of postherpetic neuralgia: A randomized, placebo-controlled trial. Neurology 2003;60:1274-83.

3. Ghori SS, Ahmed MI, Ariffudin MD, Khateeb S. Evaluation of analgesic and anti-inflammatory activities of formulation containing camphor, menthol and thymol. Int J Pharm Pharm Sci 2016;8:271-4.

4. Adebisi IM, Abubakar A, Abubakar K, Giaze TR. Analgesic effect and anti-inflammatory activity of aqueous extract Of Boswellia Dalzielii (Burseraceae) Stem Bark. Int J Pharm Pharm Sci 2018;10:1-4.

5. Anca JM, Lamela M, Calleja JM. Activity on the central nervous system of Himanthalia elongata. Planta Med 1993;59:218-20.

6. Guzmán S, Gato A, Calleja JM. Antiinflammatory, analgesic and free radical scavenging activities of the marine microalgae Chlorella stigmatophora and Phaeodactylum tricornutum. Phytother Res 2001;15:224-30.

7. Viana GS, Freitas AL, Lima MM, Vieira LA, Andrade MC, Benevides NM. Antinociceptive activity of sulfated carbohydrates from the red algae Bryothamnion seaforthii (Turner) Kutz. And B. triquetrum (SG Gmel) M. Howe. Braz J Med Biol Res 2002;35:713-22.

8. Genovese G, Tedone L, Hamann MT, Morabito M. The mediterranean red alga Asparagopsis: A source of compounds against Leishmania. Mar Drugs 2009;7:361-6.

9. Thennarasan S, Sivamurugan V, Murugesan S, Chidambaranathan N. Analgesic, anti-inflammatory and antipyretic activity of the methanol extracts of brown alga Lobophora variegata (J.V.Lamouroux) womersley ex E.C.oliveir. Am J Phytomed Clin Ther 2016;4:42-57.

10. Blunt I, Bardsley M, Dixon J. Trends in Emergency Admissions in England 2004 -2009: Is Greater Efficiency Breeding Inefficiency. London: Nuffield Trust; 2010.

11. Rangaiah GS, Lakshmi P, Sruthikeerthi K. Antibacterial activity of the crude extracts of Chlorophycean seaweeds Ulva, Caulerpa and Spongomorpha sps. against clinical and phytopathogens. Drug Inv Today 2010;2:311-4

12. Srivastava N, Saurav K, Mohanasrinivasan V, Kannabiran K, Singh M. Antibacterial potential of macroalgae collected from the Madappam coast, India. Br J Pharm Toxicol 2010;1:72-6.

13. Lavanya R, Veerappan N. Antibacterial potential of six seaweeds collected from gulf of mannar of southeast coast of India. Adv Biol Res 2011;5:38-44.

14. Kayalvizhi K, Vasuki S, Anantharaman P, Kathiresan K. Antibacterial activity of seaweeds from the Gulf of Mannar. Int J Pharm Appl 2012;3:306-14.

15. Pandithurai M, Murugesan S, Sivamurugan V. Antibacterial activity of various solvent extracts of marine brown alga Spatoglossum asperum. Int J Pharmacol Res 2015;5:133-8.

16. Murugesan S, Bhuvaneswari S, Sivamurugan V. Green synthesis, characterization of silver nanoparticles of a marine red alga Spyridia fusiformis and their antibacterial activity. Int J Pharm Pharm Sci 2017;9:1-6.

17. Hsu JL, Ruoss SJ, Bower, ND, Lin M, Holodniy M, Stevens DA. Diagnosing invasive fungal disease in critically ill patients. Crit Rev Microbiol 2011;37:277-312.

18. Di Santo R. Natural products as antifungal agents against clinically relevant pathogens. Nat Prod Rep 2010;27:1084-98.

19. Brown GD, Denning DW, Levitz SM. Tackling human fungal infections. Science 2012;336:647.

20. Tani N, Rahnasto-Rilla M, Wittekindt C. Antifungal activities of novel non-azole molecules against $S$. cerevisiae and C. albicans. Eur J Med Chem 2012;47:270-7.

21. Pandithurai M, Murugesan S, Sivamurugan V, Selvan NT. Antifungal activity of various solvent extracts of marine brown alga Spatoglossum asperum. Int J Pharm Chem 2015;5:278-80.

22. Thennarasan S, Murugesan S, Sivamurugan V. Green synthesis of silver nano particles using marine brown alga Lobophora variegata and its efficacy in antifungal activity. World J Pharm Res 2015;4:2137-45.

23. Rodríguez II, Shi YP, Garcia OJ, RodriguezAD, Mayer AM, Sanchez JA, et al. New pseudopterosin and secopseudopterosin diterpene glycosides from two colombian isolates of Pseudopterogorgia elisabethae and their diverse biological activities. J Nat Prod 2004;67:1672-80.
24. Pandithurai M, Murugesan S. Free radical scavenging activity of methanolic extract of brown alga Spatoglossum asperum. J Chem Pharm Res 2014;6:128-32.

25. Thennarasan S, Murugesan S, Sivamurugan V. Structural identification and anti-oxidant properties of methanolic extract of brown alga Lobophora variegata (J. V. Lamouroux) womersley ex E.C.oliveir. IJIPBART 2015;2:165-78.

26. Murugesan S, Bhuvaneswari S, Selvam NT. Evaluation of antioxidant property of methanolic extract of red algae Chondrococcus hornemannii and Spyridia fusiformis. J Chem Pharm Res 2015;7:333-7.

27. Kiran MV, Murugesan S. Biogenic silver nanoparticles by Halymenia poryphyroides and its in vitro anti-diabetic efficacy. J Chem Pharm Res 2013;5:1001-8.

28. Murugesan S, Babu MA, Bhuvaneswari S, Kotteswari M, Thennarasan S. In vitro antidiabetic activity of methanolic extracts of selected marine algae. Eur J Pharm Med Res 2015;2:256-60.

29. Pandithurai M, Murugesan S, Bhuvaneswari S, Thennarasan S. In vitro $\alpha$-amylase and $\alpha$-glucosidase inhibition activity of methanolic extract of marine brown alga Spatoglossum asperum. Int J Adv Pharm 2015;4:83-7.

30. Krishnamurthy V, Baluswami M. Phaeophyceae of India and Neighbourhood. Ectocarpales, Sphacelariales, Dictyotales, Chordariales and Scytosiphonales. pp. [2], i-iv, 1-193, 308 figs, pls I-VI. Vol. I. Chennai: Krishnamurthy Institute of Algology; 2010.

31. Koster R, Anderson M, De Beer E. Acetic acid for analgesic screening. Fed Proc 1959;18:412-8.

32. Williamson EM, Okpako DT, Evans FJ. Pharmacological Methods in Phytotherapy Research: Selection, Preparation and Pharmacological Evaluation of Plant Material. New York: John Wiley and Sons; 1996. p. 1-23.

33. García MD, Fernández MA, Alvarez A, Saenz MT. Antinociceptive and anti-inflammatory effect of the aqueous extract from leaves of Pimenta racemosa var. ozua (Mirtaceae). J Ethnopharmacol 2004;91:69-73.

34. Dar A, Baig HS, Saifullah SM, Ahmad VS, Yasmeen S, Nizamuddin M. Effect of seasonal variation on the anti-inflammatory activity of Sargassum wightii growing on the N. Arabian Sea coast of Pakistan. J Exp Mar Biol Ecol 2007;351:1-9.

35. Silva ED, Scheuer PJ. Manoalide, an antibiotic sesterterpenoid from the marine sponge Luffariella variabilis (Poleajaeff). Tetrahedron Lett 1980;21:1611-4

36. Chong AS, Parish CR. Non-immune lymphocyte macrophage interaction II. Evidence that the interaction involves sulfated polysaccharide recognition. Cell Immunol 1985;92:277-89.

37. Gil B, Ferrándiz ML, Sanz MJ, Terencio MC, Ubeda A, Rovirosa J, et al. Inhibition of inflammatory responses by epitaondiol and other marine natural products. Life Sci 1995;57:25-30

38. Awad NE. Biologically active steroid from the green alga Ulva lactuca. Phytother Res 2000;14:641-3.

39. Lucas R, Giannini C, Dauria MV, Payá M. Modulatory effect of bolinaquinone, a marine sesquiterpenoid, on acute and chronic inflammatory processes. J Pharmacol Exp Ther 2003;304:1172-80.

40. Jung W, Choi I, Oh S, Park SW, Seo SK, Lee SW, et al. Anti-asthmatic effect of marine red alga (Laurencia undulata) polyphenolic extracts in a murine model of asthma. Food Chem Toxicol 2009;47:293-7.

41. Payá M, Ferrándiz ML, Sanz MJ, Bustos G, Blasco R, Rios JL, et al. Study of the antioedema activity of some seaweed and sponge extracts from the mediterranean coast in mice. Phytother Res 1993;7:159-62.

42. Ming K, Jing W, Hongwen H. Demographic bottlenecks and low gene flow in remnant populations of the critically endangered Berchemiella wilsonii var. pubipetiolata (Rhamnaceae) inferred from microsatellite markers. Conserv Genet 2008;9:191-9.

43. James LR, McIntyre MD. Conditional Reasoning Test of Aggression Test Manual. Knoxville, TN: Innovative Assessment Technology; 2000.

44. James LR, McIntyre MD, Glisson CA, Bowler J, Mitchell TR. The conditional reasoning measurement system for aggression: An overview. Hum Perform 2004; 17:271-95.

45. Turner RA. In: Turner R, Ebborn P, editors. Analgesics: Screening Methods in Pharmacology. New York: Academic Press; 1965. p. 100.

46. Bisgaard H. Role of leukotrienes in asthma pathophysiology. Ped Pulmo 2000;30:166-76.

47. Bley KR, Hunter JC, Eglen RM, Smith JA. The role of IP prostanoid receptors in inflammatory pain. Trends Pharmacol Sci 1998;19:141-7.

48. Carte BK. Biomedical potential of marine natural products. Bioscience 1996;46:271-86

49. Staats PS, Yearwood T, Charapata SG, Presley RW, Wallace MS, Byas-smith $\mathrm{M}$, et al. Intrathecal ziconotide in the treatment of refractory pain in patients with cancer or AIDS-a randomized controlled trial. J Am Med Assoc 2004;291:63-70. 